\title{
The Strategy of General Election Commission (KPU) in Increasing Women's Roles in Pesawaran District*
}

\author{
Ida Farida, ${ }^{1}$ M. Ardiansyah, ${ }^{2}$ Yetti Reffiani ${ }^{3}$ \\ University of Bandar Lampung, Indonesia \\ doi) $10.15408 / \mathrm{jch} . v 9 i 1.18765$
}

\begin{abstract}
The election is the embodiment of democracy in Indonesia, the political participation of the people in elections which is implemented in the form of voting rights by people who already have the right to vote. Article 1 paragraph 2 of the 1945 Constitution of the Republic of Indonesia states that sovereignty is in the hands of the people and is exercised according to the Constitution, in its implementation, an Election is held as a process of channelling the aspirations of the people who already have rights where all citizens have the same rights to choose and be chosen to be a leader. The purpose of this research is to provide an understanding and description of the strategy of the General Election Commission in enhancing the role of women in the Regional Head Elections in the Pesawaran District in 2020. This research uses qualitative data analysis methods, namely describing and analyzing the data and data sources obtained and then described in the form of real explanation. The results showed that the strategy of the General Election Commission (KPU) of Pesawaran Regency in increasing the role of women in regional head elections was carried out by maximizing the ability of electronic media and internet media to socialize, increasing cooperation from related organizations to socialize, and Validating Voter Data.

Keywords: Strategy; General Election Commission (KPU); Role of Women; Regional Head Election; Pesawaran District
\end{abstract}

* Received: January 11, 2021, revised: February 22, 2021, accepted: March 13, 2021, Published: April 1, 2021.

${ }^{1}$ Ida Farida is a lecturer at University of Bandar Lampung. E-mail: ida.farida@ubl.ac.id

2 M. Ardiansyah is a lecturer at University of Bandar Lampung. E-mail: ardiansyahfaga1603@gmail.com

${ }^{3}$ Yetti Reffiani is a lecturer at University of Bandar Lampung. E-mail: yettireffiani76@gmail.com Corresponding Author: ida.farida@ubl.ac.id 
Ida Farida, M. Ardiansyah, Yetti Reffiani

\title{
Strategi Komisi Pemilihan Umum (KPU) Dalam Meningkatkan Peran Perempuan Di Kabupaten Pesawaran
}

\begin{abstract}
Abstrak
Pemilu merupakan perwujudan dari Demokrasi di Indonesia, Partisipasi politik masyarakat dalam Pemilu yang diimplementasikan dalam bentuk pemberian hak suara oleh masyarakat yang telah memiliki hak untuk memberikan suaranya. Pasal 1 ayat 2 UndangUndang Dasar Negara Republik Indonesia Tahun 1945 menyatakan bahwa kedaulatan berada ditangan rakyat dan dilaksanakan menurut Undang-Undang Dasar, dalam pelaksanaannya maka diadakan Pemilu sebagai proses penyaluran aspirasi rakyat yang telah memiliki hak dimana seluruh warga negara memiliki hak yang sama untuk memilih dan dipilih menjadi pemimpin. Adapun tujuan penelitian ini adalah untuk memberikan pemahaman dan gambaran mengenai strategi Komisi Pemilihan Umum dalam peningkatkan peran perempuan pada Pemilihan Kepala Daerah di Kabupaten Pesawaran Tahun 2020. Penelitian ini menggunakan metode analisis data kualitatif yaitu mendeskripsikan serta menganalisis data dan sumber data yang diperoleh kemudian dijabarkan dalam bentuk penjelasan yang sebenarnya. Hasil penelitian menunjukkan bahwa strategi Komisi Pemilihan Umum (KPU) Kabupaten Pesawaran dalam meningkatkan peran perempuan pada pemilihan kepala daerah dilakukan dengan memaksimalkan kemampuan media elektronik dan media internet untuk bersosialisasi, meningkatkan kerjasama dari organisasi-organisasi terkait untuk bersosialisasi, dan Validasi Data Pemilih.
\end{abstract}

Kata Kunci: Strategi; Komisi Pemilihan Umum (KPU); Peran Perempuan; Pemilihan Kepala Dearah; Kabupaten Pesawaran

\section{Стратегия Всеобщей избирательной комиссии (KPU) по повышению роли женщин в округе Песаваран}

\begin{abstract}
Аннотация
Выборы - это воплощение демократии в Индонезии. Политическое участие людей в выборах осуществляется в форме избирательных прав людей, которые уже имеют право голоса. Пункт 2 статьи 1 Конституции Республики Индонезия 1945 года заявляет, что суверенитет находится в руках народа и осуществляется в соответствии с Конституцией. При его осуществлении выборы проводятся как процесс отражения устремлений людей, которые уже имеют права. Все граждане имеют одинаковое право голосовать и быть избранными в качестве лидеров. Цель этого исследования - дать понимание и описание стратегии Всеобщей избирательной комиссии по повышению роли женщин на выборах главы региона в округе Песаваран в 2020 году. В этом исследовании используются методы качественного анализа данных, а именно описание и анализ данных. Источник полученных данных затем описывается в форме реального объяснения. Результаты показали, что стратегия Всеобщей избирательной комиссии (KPU) Округа Песаваран по повышению роли женщин на выборах глав региона была реализована за счет максимального увеличения возможностей электронных и интернет-СМИ к общению, расширения сотрудничества со стороны связанных организаций для общения и проверки данных избирателей.

Ключевые Слова: Стратегия; Всеобщая избирательная комиссия (KPU); роль женщин; выборы главы региона; Округ Песаваран
\end{abstract}




\section{A. INTRODUCTION}

General Election which is called Election is the manifestation of democracy in Indonesia, the implementation of the General Election is inseparable from the role of women (Khayrullovich, 2019). Due to this, the voice of women in the General Election will have a major impact on the implementation of the General Election itself. Women voters must appear as the motor to create a credible and safe election (Arnold, 2014).

On 9 December 2015, Pesawaran District had held a Regional Head Election to elect the Pesawaran District Head for the 2016-2021 period. This Regional Head Election is the first simultaneous regional election by the KPU followed by candidates such as Dendi Ramadhona and Eriawan who are promoted by the Indonesian Democratic Party of Struggle, the Democratic Party, the Gerindra Party, the National Mandate Party and the Prosperous Justice Party, then Aries Sandi Darma Putra and Mahmud Yunus who is an independent candidate, Fadhil Hakim YHS and Zainal Abidin, as well as Okta Rijaya and Salamu Solikhin, are also independent candidates.

Table of Votes for the Candidates for Regent and Deputy Regent of Pesawaran in 2015

\begin{tabular}{|l|c|c|c|}
\hline \multicolumn{1}{|c|}{ Candidate } & Party & Voters' Voice & $\%$ \\
\hline $\begin{array}{l}\text { Dendi Ramadhona- } \\
\text { Eriawan }\end{array}$ & $\begin{array}{c}\text { Indonesian Democratic Party of } \\
\text { Struggle (PDI Perjuangan), Democratic } \\
\text { Party (Partai Demokrat), Gerindra Party, } \\
\text { National Mandate Party (PAN), } \\
\text { Prosperous Justice Party (PKS) }\end{array}$ & 108.271 & $47,08 \%$ \\
\hline $\begin{array}{l}\text { Aries Sandi Darma } \\
\text { Putra-Mahmud Yunus }\end{array}$ & \multicolumn{1}{|c|}{ Independent } \\
\hline $\begin{array}{l}\text { Fadhil Hakim YHS- } \\
\text { Zainal Abidin }\end{array}$ & 67.800 & $29,48 \%$ \\
\hline $\begin{array}{l}\text { Okta Rijaya-Salamu } \\
\text { Solikhin }\end{array}$ & 39.474 & $17,17 \%$ \\
\hline \multicolumn{2}{|c|}{ Invalid / Not Voting (Golput) } & 14.416 & $6,27 \%$ \\
\hline \multicolumn{2}{|c|}{ Total Valid Votes } & 3.727 & $100 \%$ \\
\hline \multicolumn{2}{|c|}{ Registered voters } & 229.682 & $70,07 \%$ \\
\hline
\end{tabular}

Source: General Election Commission (KPU) of Pesawaran District 
In the Election Implementation, some people do not exercise their rights in the election, the term group white (golput) is a term often used in politics for people or groups who refuse to use their voting rights in general elections (Farida et al, 2020). The refusal to use their voting rights can be due to several ideological reasons, such as a crisis of trust in state institutions, promises and idealism of nationalism, political parties, etc., this is influenced by internal and external factors of a voter according to Arianto (Dube \& Danescu, 2020).

The internal factors of a person, not choosing are caused by 2 (two) things, namely:

1. Technical factors, there are technical constraints that prevent them from exercising their right to vote. This factor can be classified into (2) two things, namely:

a. Absolute technicality is an obstacle that immediately makes voters unable to attend polling stations (TPS), such as being sick, being out of town.

b. Techniques that can be tolerated are simple problems inherent in voters, such as family needs, planning holidays on election day. In cases like this one can still work on it, namely by first coming to the polling station (TPS) and then carrying out personal activities.

2. Employment factors, most of Indonesia's population work in the informal sector where income greatly affects the intensity of work, jobs that require them to leave their homes, such as seafarers, mining workers, this condition makes them unable to go to polling stations (TPS) due to its location. far from where he works.

External factors that make people choose not caused by 3 (three) things, namely:

a. Administrative factors related to administrative aspects that result in voters not being able to use their voting rights, such as not being registered in the voter list, not having a population identity, if this is the case then the public will automatically join the white class.

b. Disseminating information or disseminating it is very important to avoid the white group, because most of the Indonesian population are in rural areas, disseminating information about elections is considered very important, especially for people who are far from information and transportation. 
c. Political factors that are the reasons for the political effect of people not wanting to vote, such as distrust of parties, have no choice of candidates. Another factor is politicians who have no roots, politicians who are close to and fight for people's aspirations.

Another phenomenon is the campaign on behalf of the community with the target of women as the target of the campaign besides the practice of money politics that often occurs in the target community is women, the existence of black campaigns or known as the Black Campaign is the task of the General Election Commission (KPU), in the General Election Election administrators to protect the voting rights of the people through political education, among others, through election socialization (Siregar et al, 2020).

Currently, the total population of Pesawaran District, which is registered in the Permanent Voters List (DPT), is 329.655 people, 160.339 female voters and 169.316 male voters. Whereas in the 2015 Regional Head Elections (Pilkada) the number of voters was 334.288, 163.238 female voters and 170.420 male voters, while those who exercised their voting rights were 116.942 women and 116.959 men. the overall percentage is $70.07 \%$, while the national target is $77.5 \%$.

\section{B. METHODS}

This study uses qualitative data analysis methods, namely describing and analyzing data and data sources obtained and then described in the form of an actual explanation (Setiawan, 2017). The data analysis used in this study is a qualitative descriptive data analysis method from Milles and Huberman (Setiawan, 2016) which includes four components, namely; Data collection, data reduction, data presentation, concluding.

This research was conducted in Lampung Province, precisely in Pesawaran District. The selection of informants as data sources in this study is based on the principles of subjects who master the problem, have adequate data and are willing to provide complete and accurate information (Valiullova, 2015). The informant who acts as the source of the information must meet these requirements, which will be the key informant and supporting informant. As key informant of the General Election Commission (KPU) of Pesawaran Regency. while the supporting informants of secondary informants consist of the Election Supervisory Body (Bawaslu) of Pesawaran District, Political Parties and the People of Pesawaran District. To be more clearly described in the table below: 
Table 3.1

Research Informants

\begin{tabular}{|c|l|c|}
\hline $\begin{array}{c}\text { Informant } \\
\text { Code }\end{array}$ & \multicolumn{1}{|c|}{ Informant } & Status \\
\hline 11 & $\begin{array}{l}\text { The General Election Commission (KPU) of Pesawaran } \\
\text { Regency }\end{array}$ & Key informant \\
\hline 12 & $\begin{array}{l}\text { Pesawaran District Election Supervisory Agency } \\
\text { (Bawaslu) }\end{array}$ & secondary informant \\
\hline 13 & Political Parties & secondary informant \\
\hline 14 & Pesawaran District Community & secondary informant \\
\hline
\end{tabular}

Source: Research Results 2019 (processed data)

In this study the data collection process was carried out by (Farida \& Setiawan, 2018):

a. Library research, namely by searching for supporting literature, official documents, and the results of previous research related to research that can support the author in discussing the proposed problem.

b. Field research is research conducted on the object or location of the study with the hope of obtaining empirical data, using methods such as; Observation, Interview, and Documentation.

\section{RESULTS}

This study uses data from interviews, observations and documents obtained during the KPU strategy research in increasing the role of women in the 2020 Pilkada Pesawaran, with a SWOT analysis according to Kotler (Kingdon, 2003) consisting of: Strengths, Weaknesses, Opportunity, Threats.

Increasing the role of women or women's participation in the General Election is one of the duties of the KPU as an election administering institution. After all, the success of the election can be seen from the level of voter participation, in this case, the role of women in the election is very important because most of the people of Pesawaran District are women, with the vision of the Pesawaran Regency KPU. To become an independent, impartial, nonparticipant, transparent and professional Election organizer based on the principles of democratic elections by involving the widest possible public participation so that the public can trust credible results with a socialization 
strategy to achieve results in line with the expectations of achieving targets There are 11 (eleven) bases of socialization, namely: family, beginners, youth, women, people with disabilities, with special needs, marginal groups, religions, democratic communities, internet citizens (Setiawan et al, 2020). And in the eleven bases, there are women in which this is one of the targets in socialization (Garipov \& Zaznaev, 2013). The implementation of this strategy has internal factors as well as external factors faced by the KPU in Pesawaran District, which will be analyzed using SWOT.

\section{Strengths}

In making policies, the KPU of Pesawaran District pays close attention to internal and external factors, including in deciding strategies to increase the role of women in the 2020 Pilkada Pesawaran. From the results of the interview with Mr YP:

"The strengths we have include experienced and reliable personnel. Elections are no longer something new because we have held several General Elections, while for this Pilkada will be the third time in Pesawaran District, and in carrying out every stage of the Election we comply with government regulations in the form of laws ". (interview with Y, Chairperson of the Pesawaran Regency KPU, financial, general and logistics division, 19 November 2019, at 13.25 WIB, Pesawaran Regency KPU Office).

From the results of the interview, it can be seen that one of the strengths of the Pesawaran Regency KPU is experienced and reliable personnel working together in every activity, the Pesawaran Regency KPU has had skilled and potential human resources with divisions in the implementation of their duties, Yatin Putro Sugino, as the Head of the KPU of the Pesawaran Regency division, Murniati Indah Permata Sari, as a member of the Pesawaran Regency KPU, the Parmas and HR Division, Muhammad Wasito, member of KPU Regency of Pesawaran, Legal Division, Yudi Andriansyah, member of KPU of Pesawaran Regency, General Finance and Logistics Division, Dody Afriyanto, member of KPU of Pesawaran Regency, Program and Data Division, Sofiani, Secretary of KPU of Pesawaran Regency, Firdaus, Head of Subdivision of Technical and Hupmas, Putri Ramadanti, Head of Subdivision of Programs and Data, Yuliza Fitrianti, as staff of the technical and hupmas subdivision with an educational background who have and participate in various technical training courses held by the General Election Commission, making secretariat personnel who are experts able to use the infrastructure effectively and efficiently. In connection with the interview with the Secretary of the Pesawaran Regency KPU, namely: 
"The commissioners of the KPU of Pesawaran Regency have different backgrounds, there are those from the economy, government and elements of education, they work together to complement each other in carrying out their duties to be successful, especially if one of the five members was a member of the Commissioner in the previous period. experience in previous elections". (Interview with S, 19 November 2019, Secretary of the Pesawaran Regency KPU, at 10:05 WIB at the Pesawaran Regency KPU Office).

From the interview above, it can be concluded that in the decision making process of the KPU in Pesawaran Regency, using the collective principle of colleges, namely all policies based on the principle of musawarah mupakat, namely that all management and members must be involved in the KPU policy, which is not determined by one person, for example, the chairperson or individual. Therefore it is demanded that each individual must be solid in maintaining and maintaining cohesiveness. Discipline attitude of Pesawaran Regency KPU employees who work according to the Election stages who do not recognize working hours.

Following Law Article 10 Number 15 of 2011 concerning General Election Organizers, as an institution that organizes technically according to its stages.

Interview with YP, Chairman of the Pesawaran Regency KPU:

"Another advantage that the Pesawaran Regency KPU has is the authority given the mandate to hold the General Election. This is stated in Law Number 15 of 2011 Article 10 concerning Election organizers." (Interview with the Chairperson of the Pesawaran Regency KPU, 16 December 2019 at 13.25 WIB, at the Pesawaran Regency KPU Office).

From the interview, it was concluded that the KPU of Pesawaran District had the legal force as an election organizer which was mandated by the Government as an Election Management Institution based on Law Number 15 of 2011 Article 10 concerning General Election Administrators.

\section{Weaknesses}

Weakness is a limitation or lack of things that must be overcome or corrected. In increasing the number of women in the upcoming elections, this must be addressed properly.

Interview with the Chairperson of the Pesawaran YP Regency KPU: 
"In carrying out this Pilkada stage, we are still constrained by a lack of personnel. With only 16 (sixteen) employees minus 3 (three) people on study assignments so only 13 (people) are active in the office, this is an obstacle in carrying out the stages. Pilkada, especially the socialization program ". (Interview with the Chairman of the KPU KPU Pesawaran Regency, 16 December 2019, at 12:18 WIB in the room of the members of the Pesawaran Regency KPU).

From the interview above, the KPU, Pesawaran District, still lacks human resources in carrying out its duties in carrying out every stage of the elections. This is like the statement made by MI, the Head of the HR and Parmas Division:

"Based on KPU Circular Letter Number 15 of 2016, ideally Regency/City Employees are 17 (seventeen) people, but here only 16 (sixteen) people, 3 (three) more people have study assignments so only 13 (thirteen) people active, plus honorary 8 (eight) people consisting of a driver, maid service and office guard, assisted by 9 (nine) contract workers. (Interview with the Head of the HR and Parmas Division, 16 December 2019, at 12:18 WIB in the room of the members of the Pesawaran Regency KPU).

Based on the interview above, human resources are a very important element in the implementation of activities in the stages of Regional head elections stages with a shortage of personnel being an obstacle to achieving an increase in the role of women in the upcoming 2020 elections. The KPU of Pesawaran Regency found an obstacle in implementing the socialization later, this was due to the geographic location of Pesawaran Regency which was far away and partly difficult to reach because of the mountainous and island areas with limited personnel became an obstacle in carrying out socialization in the area.

Interview with members of the political party W PDIP Party:

"To increase the role of women in the Pesawaran Regional head elections, we also held socializations such as political campaigns targeting recitation mothers, housewives. This socialization in addition to helping prospective election participants also helps the KPU in voter education programs". (Interview with W members of the PDIP political party, December 9, 2019, at 13:15 WIB, the PDIP DPC Office of Pesawaran Regency).

From the results of the interview above, the Political Party also has a program of outreach activities to increase the role of women in the 2020 elections, because the campaign targets are mostly women. This is very helpful for the Pesawaran Regency KPU to increase the role of women in the 2020 elections. In the socialization efforts carried out by political parties, it is hoped 
that the public will be able to find out the profiles of candidate election participants and be able to understand the procedures for channelling aspirations in the upcoming regional elections, further coordinating with stakeholders (Setiawan \& Melinda, 2020). As the organizer, it must be wellcoordinated, as is the relationship with Bawaslu of Pesawaran District.

Interview with Bawaslu members of Pesawaran R Regency:

"In every stage of the Regional head elections, we as a supervisory agency always supervises the implementation of the Pilkada, long before the Regional head elections stage begins we have sent a warning letter to remind the KPU in carrying out the Pilkada stages" (Interview with $\mathrm{R}$, Bawaslu member of Pesawaran Regency, 09 December 2019, 02.00 WIB at the Office. Bawaslu Secretariat of Pesawaran District).

From the results of the interview, the stakeholder is a partner of the KPU in the Election Implementation in carrying out its work program as election supervisor.

\section{Opportunity}

In an organization, it must be able to take advantage of opportunities by minimizing existing weaknesses and be able to formulate strategies that are tailored to exist conditions in the field, Kpu has the opportunity to implement strategies in increasing the role of women in the regional elections. This was conveyed by the Head of the HR and Parmas MI Division, as follows:

"This opportunity includes utilizing internet technology to carry out socialization on social media. (Interview with the Head of the HR and Parmas Division of Pesawaran District, 16 December 2019, at 01.00 WIB, at the KPU Office of Pesawaran Regency).

From the interview above, the KPU of Pesawaran District has utilized internet technology properly to support the Regional Head Election Socialization Program.

\section{Threats}

It is a condition where this threat can disrupt the organization in the implementation of the elections. Interview with the head of the technical division Chair of the Technical and Hupmas division YA: 
"Threats in carrying out the Regional head elections stages can be from within or from outside the organization". (Interview with the Head of the Technical and Hupmas Division of the Pesawaran Regency KPU, 16 December 2019, at 01.00 WIB, at the Pesawaran Regency KPU Office).

From the interview above, it can be seen that every Election implementation must have a power struggle, this can trigger claims or demonstrations from the losing party in the Election competition, threats both from within the organization and from outside the organization itself.

\section{DISCUSSION}

The Strategy of the General Election Commission (KPU) in Increasing the Role of Women in the 2020 Election of the Regent and Deputy Regent of Pesawaran

Is the content of the results of data and facts researched in the field and adjusted to the theory used? The discussion of research results to provide the interpretation obtained during the research using the SWOT analysis in Kotler (Kingdon, 2003). Is an evaluation of all Strengths, Weaknesses, Opportunities and Threats, which exist in individuals or organizations? This theory uses an overview of the important components that are considered by leaders in making effective strategic policies including 4 factors, namely Strength, Weaknesses, Opportunities and Threats.

\section{Strength}

Analysis of the strength elements possessed by the organization (Stone, 2012). or other elements of strength that emphasize organizational excellence (Holzer \& Lee, 2004). From the results of research in the field of strength that the KPU has, the staff and employees of the KPU in Pesawaran Regency can work together well according to their respective fields and divisions, members who are experts work together well, and government support in the form of laws. In addition to having experts in their fields so that they can use the existing facilities and infrastructure in the KPU effectively and efficiently, in making decisions with the collegial collective is a leadership system that involves parties with an interest in issuing decisions or policies through the mechanisms adopted, deliberations to reach consensus or voting, by promoting the spirit of togetherness. The performance of KPU employees has been maximized by working according to the calendar instead of working hours and 
in increasing understanding of the main duties and functions of each division, training and training are often held following each division, to carry out the vision and mission, KPU Pesawaran, then KPU has full authority to hold elections and is supported by the government in the form of laws and regulations containing technical instructions for the KPU in holding elections, then the KPU Pesawaran in increasing the role of women in elections has a socialization program that is held on 11 (eleven) bases which aims to provide election education with an understanding of the importance of elections in democratic life, concerning stages and programs, regarding election techniques and raising awareness of voters, especially women, in channelling their aspirations by exercising their voting rights in the General Election.

PKPU 15 of 2019 Stages, Programs and Schedule for Organizing the Election of Governors and Deputy Governors, Regents and Deputy Regents, and/or Mayor and Deputy Mayor of 2020, 16 of 2019 General Election Commission Regulation of the Republic of Indonesia Number 16 of 2019 concerning Amendments to Regulations The General Election Commission Number 15 of 2019 Concerning the Stages, Programs and Schedule for Organizing the Election of Governors and Deputy Governors, Regents and Deputy Regents, and/or Mayors and Deputy Mayors in 2020. PKPU 18 of 2019 General Election Commission Regulation of the Republic of Indonesia Regarding the Second Amendment to the General Election Commission Regulation Number 3 of 2017 concerning Nominations for the Election of Governors and Deputy Governors, Regents and Deputy Regents, and/or Mayors and Deputy Mayors.

\section{Weaknesses}

Analysis of the elements of weakness that the organization has or elements of weakness or lack of resources, skills and abilities are weaknesses that can hinder the progress of the organization, in the study, it was found that there were still deficiencies or weaknesses in the Pesawaran Regency KPU, among others, still lacking employees. In this case, the Pesawaran district KPU only has 16 employees, which should be 17 , even then 3 fewer people are on study assignments so only 13 people are active in the office, and assisted by 7 honorary staff consisting of security guards, maids, and drivers. honorer is also a contracted employee. The KPU of Pesawaran Regency is assisted by 9 outsourcing workers even if there are election activities only because of the nature of the contract. KPU circular letter number 5 of 2016 regulates the number of Regency/City KPU employees as many as 17 employees in each 
Regency / City, if there are no election stage activities, if there are election stages then it is added with contract labour (outsourcing).

This human resource problem becomes an obstacle for the KPU in the implementation of the General Election because it has an impact on the performance of the KPU, especially since the area of Pesawaran District is quite wide and consists of lowland highlands, as well as islands which are far apart and have a large population, with less personnel. Adequate is an obstacle for the KPU in maximizing the socialization later, and the heavy workload makes the Pesawaran Regency KPU an obstacle in carrying out the stages of the Election (Pilkada). Then at the level of work understanding level, the employees of the KPU in Pesawaran Regency still do not understand well their workloads so they often experience delays in completing tasks.

To improve the quality of employees by including employees in training, technical guidance, coordination meetings related to regulations, FGDs, briefings, understanding of the program to be implemented is still not following expectations this greatly affects performance and results in less than optimal socialization due to lack of technical understanding election stages (Setiawan, 2019). Pesawaran Regency KPU also utilizes social media in socialization programs such as Facebook, Instagram, What's App and Web KPU Pesawaran Regency.

To increase the role of women in the Pilkada which is very important, one of which is financial support, this is related to socialization. In fact, in terms of the budget, the KPU has submitted a budget to the Pesawaran District Government in the amount of Rp. 39,665,606,000, - but only Rp. 28,208,572,000, with a minimal budget means that all activities in the stages of the Election must be able to use the budget as well as possible and this has an impact on the 11 (eleven) basis socialization programs in society, namely: Family, Women, Youth, Women, Persons with Disabilities, Needs specifically, marginalized people, community, socialization basis, democratic community, internet citizens (Golubeva et al, 2019).

\section{Opportunities}

The ability to take advantage of opportunities must be possessed by an organization by minimizing existing weaknesses and being able to formulate strategies that are following the conditions in the field, such as digital use in the era of digitalization (Kusuma \& Setiawan, 2018), the KPU must be able to 
capture and take advantage of opportunities that exist in society today by referring to developed countries. in democracy.

In increasing the role of women, there are opportunities for good cooperation with traditional leaders, community leaders, religious leaders and so on so that the socialization is right on target. Another opportunity for stakeholders, such as Bawaslu of Pesawaran District, to have a socialization program, is also an opportunity for the KPU to increase the role of women in the 2020 elections (Regional head elections). Other stakeholders such as the PDIP Political Party also have their own Pilkada socialization program in the form of a campaign to elect the candidates they carry, recently coinciding with Mother's Day, which falls on Sunday, December 22, PDIP held an event in the Sidototo field with around 300 participants. people, consisting of the general public, recitation mothers, PDIP female cadres.

Relationships with other stakeholders must continue to be wellcoordinated, support from stakeholders such as Bawaslu, Pesawaran District, is one of the opportunities for the Pesawaran Regency KPU, besides Bawaslu, Pesawaran Regency has its program in disseminating the Election Bawaslu also has the task of overseeing every stage of the Election (Pilkada), supervising if There were violations both by election participants and by-election organizers. Bawaslu also has a socialization program such as: starting from Stakeholders, Toga (religious leaders), Toma (community leaders), Adat figures for participatory supervision involving mothers and students, there are about 5 (five) times the socialization which is part of the Bawaslu program of Pesawaran District.

Other opportunities to facilitate the KPU of Pesawaran Regency in increasing the role of women in the Pilkada include mass organizations: Family, Beginners, Youth, Women, People with Disabilities, Special Needs, Marginalized People, Religious, Democratic Communities, Internet citizens, are expected to save time, cost right targeted and efficient and effective, another goal so that less representative in the socialization is expected to disseminate the socialization (Homberg et al, 2019).

\section{Threats}

It is a threat that comes from outside that can interfere with the organization in carrying out its duties because as political competition is related to power struggles this can lead to conflict (Nasi, 2011). 
Another threat of changing laws is this causes misunderstanding, not yet understanding the old law, the emergence of a new law song, this is sometimes confusing, concerning the changing laws and regulations, for example, PKPU Number 15 concerning the stages, programs, and schedules have just been issued, there have been changes to PKPU Number 16 in place of PKPU 15 of 2019.

As for threats such as logistical distribution is constrained by bad weather factors, such as rain, it is necessary to anticipate and monitor the public apathy towards the Pilkada itself, by being indifferent, indifferent, not interested in the Pilkada, one of the factors in the emergence of such attitudes is the figure of contestants. that didn't change, there were no new contestants (Peters \& Pierre, 2003). That gave off a feeling of boredom and disinterest.

Based on the strategy described, the researcher agrees with the strategy that will be carried out by the KPU of Pesawaran Regency in the future, this is following the theory of SWOT analysis techniques in Kotler (Kingdon, 2003) which consists of strengths, weaknesses, opportunities, threats (threats), this strategy can simplify and assist the Pesawaran Regency KPU in fixing the weaknesses of the strategies that will be implemented, increasing employee understanding and taking advantage of existing opportunities such as the use of internet technology this strategy takes advantage of the strengths of the Pesawaran Regency KPU to fix weaknesses, KPU Pesawaran District will take advantage of existing opportunities such as information technology and minimize any threats aimed at Pesawaran KPU. Furthermore, the strategy of observing the external environment and the internal environment, the internal environment includes strengths and weaknesses and the external environment includes opportunities and threats, for the long term the KPU of Pesawaran District carries out a strategy which is the development of a long-term plan and improves the quality of elections in Pesawaran District, this is the implementation of vision and mission of the Pesawaran Regency KPU.

\section{E. CONCLUSIONS}

Based on the results of research and discussion of the strategy of the Pesawaran Regency KPU in increasing the role of women in the Pemilukada of Pesawaran Regency by using the SWOT analysis in Kotler (Kingdon, 2003) from the results of the study using 4 variables, the following conclusions can be drawn: 
a. The strategy of the Pesawaran Regency KPU by identifying the mission of the Pesawaran Regency KPU, the second is the strategic environmental analysis with the SWOT analysis, and the third is the strategic issue analysis.

b. The strategy of the KPU in Pesawaran Regency in increasing the role of women in regional head elections, among others: Maximizing the ability of electronic media and internet media to socialize, Increasing cooperation from related organizations to socialize, and Validating Voter Data.

\section{REFERENCES:}

Arnold, G. "Policy learning and science policy innovation adoption by street level bureaucrats", Journal of Public Policy, Volume 34 Number 3 (2014).

Dube, S., \& Danescu, D., "Supplemental Guidance: Public Sector Definition", The Institute of Internal Auditors, https://global.theiia.org/standardsguidance/Public\%20Documents/Public\%20Sector\%20Definition.pdf, downloaded on July 19, 2020.

Farida, I. \& Setiawan, R., “Leadership in Cope with Prostitute in Social

Department of Bandar Lampung" International Journal of Social Sciences and Development, Vol. 2 (1), (2018).

Farida, I., Setiawan, R., Maryatmi, A.S., \& Juwita, M.N. “The Implementation of E-Government in The Industrial Revolution Era 4.0 in Indonesia" International Journal of Progressive Sciences and Technologies, Vol. 22 (2), (2020).

Garipov, R. F., \& Zaznaev, O. I., "Political Responsibility of The Head of The The region in Modern Russia" Bulletin of the Saratov University, Volume 13 Number 2 ( 2013).

Golubeva, A. A., Gilenko, E. V., \& Dzhedzheya, V. B. “Enhancing Public Value of Local Public Services through Electronic Interaction", Russian Management Journal, Volume 17 Number 2 (2019).

Holzer, M. \& Lee, S. Public Productivity, New York: Marcel Dekker, 2004. 
Homberg, F., Vogel, R., \& Weiherl, J. “Public service motivation and continuous organizational change: Taking charge behaviour at police services", Volume 97 Number 1 (2019).

Khayrullovich, M. F., "State Council of The Republic of Tatarstan: Parliament At

The Service of Society Interests", Current Problems of Theory and Practice of Constitutional Proceedings, Volume 14 Number 1 (2019).

Kingdon, J. W. Agendas, Alternatives, and Public Policies, United of Kingdom: Longman, 2003.

Kusuma, Y., \& Setiawan, R., “Start-Up of Creative Industry of Additives

Onggok Charcoal Additives (International Conference on Low Carbon City Design, Japan)--(Section: Energy and Environment)", JAILCD / Asian Institute of Low Carbon Design, 255-258, (2018).

Nasi, G. "Public Personnel Policies: Impact on Government Performance", Journal of Comparative Policy Analysis: Research and Practice, Volume 13 Number 1 (2011).

Peters, B. G. \& Pierre, J. Public Administration, London: Sage, 2003.

Setiawan, R. “Evolution of Tatarstan's Local Self-Governments and Challenges They Face” ‘ADALAH, Vol. 3 (5) (2019).

Setiawan, R. "Partisipasi Publik Dalam Program Bantuan Listrik Pedesaan Masyarakat Kabupaten Mesuji" Jurnal e-JKPP, Vol. 3 (3) (2017).

Setiawan, R. "Peranan Etika Aparatur Sipil Negara Dalam Pelayanan Publik Pada Dinas Kependudukan Dan Catatan Sipil (Disdukcapil) Kota Bandar Lampung" Jurnal e-JKPP, Vol. 2 (2) (2016).

Setiawan, R., Esti, M., Sidorov, V.V, "Islam and Politics in Indonesia" RUDN Journal of Political Science, Vol. 22 (4) (2020).

Setiawan, R., \& Melinda, E., “Optimization of the Implementation of Village Government in Indonesia" RUDN Journal of Public Administration, Vol. 7 (4) (2020).

Setiawan, R., Sulthan, M.F., Abdurrahman, A., "Government Policy in Public FSH UIN Syarif Hidayatullah Jakarta In Association with Poskolegnas UIN Jakarta - 127 
Services in the Republic of Tatarstan, Russia" Jurnal Cita Hukum, Vol. 8 (3) (2020).

Siregar, F.A., Heryanto, G.G., Muqsith, M.A.,\& Setiawan, R., “Prosperous Justice Party (PKS) Image Management In The 2019 Election" SALAM: Jurnal Sosial dan Budaya Syar-i, Vol. 7 (11) (2020).

Stone, D. Policy Paradox: The Art of Political Decision Making, Norton \& The company, 2012.

Valiullova D. R., "State Youth Policy: Experience of The Republic of Tatarstan", Conference: Legal and Socio-Pedagogical Aspects of Prevention of Offenses of Minors and Youth, Elabuga on April 17, 2015. 